\title{
PEMANFAATAN DANA WAKAF TUNAI UNTUK PEMBIAYAAN PEMBANGUNAN INRASTRUKTUR
}

\author{
Ahmad Syafiq \\ Bawas Mahkamah Agung Republik Indonesia \\ e-mail: stafiq.ahmed99@gmail.com
}

\begin{abstract}
The cash waqf funds can be used for financing the construction of infrastructure projects, since basically the purpose between infrastructure and wakaf development is the same that is to improve the social welfare of the people (ummah). However, since waqf funds belong to the general public handed over to the Waqf Board to be managed, in the inclusion of waqf funds as a source of funds for infrastructure projects development, it is necessary to prioritize prudential aspects so that wakaf funds can again provide sustainable benefits and can be used again for the empowerment of other people.
\end{abstract}

Keywords: Cash Waqf, Financing, and Infrastructure.

\section{Pendahuluan}

Pemerintah dalam menjalankan peranannya senantiasa berupaya menyediakan barang dan pelayanan yang baik untuk warganya terutama dalam penyediaan infrastruktur. Penyediaan infrastruktur merupakan tanggung jawab pemerintah bagi 


\section{Ahmad Syafiq}

warga negaranya karena infrastruktur tidak hanya dipandang sebagai public goods tetapi lebih kepada economic goods, oleh karena itu, pemerintah memiliki kepentingan untuk membangun infrastruktur yang penting bagi masyarakat.

Pemerintah saat ini sedang gencar untuk membangun infrastruktur. Dengan porsi anggaran yang terus meningkat setiap tahun, Pemerintah gencar membangun infrastruktur di sebagian besar wilayah di Tanah Air. Fokusnya tidak hanya di Jawa, melainkan hingga pelosok daerah dan kawasan perbatasan. Anggaran proyek strategis dan prioritas sampai dengan 2019 memang terbilang besar, yakni mencapai Rp. 4.197.000.000.000.000,00 (emat ribu seratus sembilan puluh tujuh triliun rupiah). Pemerintah dan Badan Usaha Milik Negara (BUMN) serta Badan Usaha Milik Daerah (BUMD) mengambil porsi 42,5 persen. Sisanya, dari Investasi swasta. Sampai dengan Tahun 2017, menurut data Kementerian Keuangan, pemerintah sudah mengeluarkan pembiayaan dari APBN sebesar Rp. 994.700.000.000.000,00 (sembilan ratus sembilan puluh empat triliun tujuh ratus miliar rupiah) (Tempo, $2017: 55$ ).

Pembangunan infrastruktur sendiri dapat dilakukan dengan berbagai pola antara lain:

a) Proyek Pemerintah Pusat atau Daerah yang dibiayai oleh APBN atau APBD. Pembangunannya dilaksanakan oleh BUMN/BUMD/swasta. Sumber dananya bisa melalui: Rupiah murni, atau Pinjaman/hibah luar negeri (lembaga multilateral/ bilateral/kredit ekspor), biasanya disertai dengan rupiah pendamping

b) Proyek BUMN/BUMD, yang dibiayai oleh anggaran perusahaan sesuai dengan RKAP yang disetujui oleh Meneg BUMN/Pemda.

c) Proyek Kerjasama Pemerintah-Swasta (Konsesi), yang dibiayai oleh modal investor swasta, pinjaman perbankan/ pasar modal domestik dan luar negeri. Peran 
Pemerintah hanya memberikan dukungan untuk proyek yang kurang menarik minat swasta, tetapi mempunyai kelayakan ekonomi yang tinggi.

Terbatasnya dana yang dimiliki, menyebabkan pemerintah tidak mampu membiayai pembangunan seluruh infrastruktur yang dibutuhkan oleh masyarakat seperti jalan, jembatan, jaringan air minum, dan pelabuhan. Sesuai data dari BAPENAS, diketahui bahwa estimasi kebutuhan investasi infrastruktur pada tahun 2010-20014 sebagaimana digambarkan dalam grafik dibawah ini:

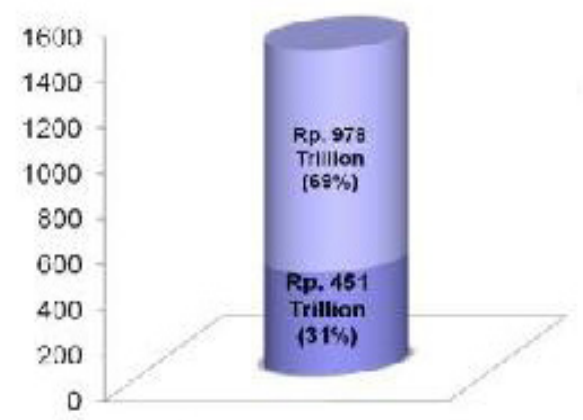

Financing Gap: expected to be covered through PPP, CSR, participation Estimated GOV Financing Capacity

Dari grafik diatas, terdapat informasi bahwa dari total biaya yang dibutuhkan untuk pembangunan infrastuktur, hanya + 31\% saja yang mampu untuk dibiayai oleh pemerintah melalui APBN, sementara sisanya yang $+69 \%$ direncanakan diperoleh dari sumber lain di luar APBN.

Dengan melihat fakta diatas, maka peran swasta dalam pembangunan infrastruktur sangat dibutuhkan sehingga pendanaan atau investasi untuk pembangunan infrastruktur dapat terpenuhi. Bentuk kerjasama ini biasa dikenal dengan istilah kerjasama pemerintah swasta atau konsesi (www.kppu.go.id).

Menurut Ketua Pokja Pendirian Bank Wakaf, Zainulbahar Noor, berdasarkan studi Islamic Development Bank (IDB), potensi zakat di Indonesia mencapai Rp 215 triliun, sedangkan potensi wakaf sebesar Rp 100 triliun. Hal ini bukanlah sesuatu yang kecil, melainkan sangat besar manfaatnya apabila dapat digunakan 


\section{Ahmad Syafiq}

untuk kepentingan masyarakat. Terlebih apabila dana wakaf tersebut dapat digunakan untuk membiayai pembangunan infrastruktur.

Data Dewan Wakaf Indonesia menunjukkan bahwa sampai Januari 2017, total aset wakaf dalam bentuk properti atau lahan telah mencapai 4,4 miliar meter persegi. Perkiraan ni lai ekonominya mencapai Rp 370 triliun. Namun, sebagian besar lahan wakaf tersebut hanya digunakan untuk pembangunan sekolah, masjid, atau pemakaman umum. Menurut Menkeu Sri Mulyani Indrawati, lahan wakaf itu bisa memberikan manfaat lebih bagi masyarakat jika digunakan untuk properti yang menghasilkan keuntungan.

Berdasarkan hal-hal tersebut diatas, maka penulis tertarik untuk membahas tentang bagaimanakah pemanfaatan harta wakaf untuk pembiayaan pembangunan infrastruktur?

\section{Pembahasan}

\section{Pengertian wakaf uang}

Kata wakaf atau waqf berasal dari bahasa Arab yang berasal dari akar kata wa-qa-fa berarti menahan, berhenti, diam di tempat atau berdiri. Kata waqafa-yaqifu-waqfan semakna dengan kata habasa-yahbisu-tahbisan maknanya terhalang untuk menggunakan. Kata waqf dalam bahasa Arab mengandung makna, artinya: menahan, menahan harta untuk diwakafkan, tidak dipindahmilikkan. (al-Mishri, tt.: 11/276) Menurut istilah meskipun terdapat perbedaan penafsiran, disepakati bahwa makna wakaf adalah menahan dzatnya benda dan memanfaatkan hasilnya atau menahan dzatnya dan menyedekahkan manfaatnya (Abu Zahrah, 1971: 41).

Pengertian wakaf tunai atau wakaf uang adalah wakaf (menahan harta/ penyerahan aset) yang dilakukan oleh sekelompok atau seseorang maupun badan hukum yang berbentuk wakaf tunai berupa uang, termasuk dalam pengertian 
uang adalah surat - surat berharga, atau dapat didefinisikan wakaf tunai adalah penyerahan aset wakaf berupa uang tunai yang tidak dapat dipindah tangankan dan dibekukan untuk selain kepentingan umum yang tidak mengurangi ataupun jumlah pokoknya. Dalam bahasa fikih disebut dengan wakaf dinar dan dirham (Ibn <Abidin, tt.: 552).

Istilah wakaf uang juga biasa disebut dengan wakaf produktif. Hanya saja wakaf produktif cakupannya lebih luas, karena selain mencakup wakaf uang, juga mencakup wakaf harta tidak bergerak yang diproduktifkan (Undang-Undang nomor 41 tahun 2004 tentang Wakaf). Wakaf produktif adalah wakaf harta yang digunakan untuk kepentingan produksi, baik di bidang pertanian, perindustrian, perdagangan dan jasa yang manfaatnya bukan pada benda wakaf secara langsung, tetapi dari keuntungan bersih hasil pengembangan wakaf yang diberikan kepada orang-orang yang berhak sesuaidengan tujuan wakaf. Wakaf produktif dapat mengacu kepada dua hal pokok, yaitu satu, harta tetap (tidak bergerak) seperti tanah, rumah, toko dan harta tidak tetap (bergerak) seperti hewan, buku dan lain-lain. Utamanya adalah bagaimana harta wakaf itu bisa produktif (berkembang). Bendanya bisa jadi tetap, tetapi pemanfaatannya berkembang secara ekonomis. Kedua, wakaf produktif dalam arti wakaf uang/tunai (PP Nomor 42 tahun 2006).

\section{Dasar hukum wakaf uang}

Dalam al-Quran surat Ali Imran ayat 92 disebutkan bahwa: "Kamu sekali-kali tidak akan sampai kepada kebaikan (yang sempurna) sebelum kamu menafkahkan sebahagian harta yang kamu cintai, dan apa saja yang kamu nafkahkan maka sesungguhnya Allah mengetahuinya." (QS. Ali Imran: 92).

Ayat lain tentang sedekah adalah: "Perumpamaan (nafkah yang dikeluarkan oleh) orang-orang yang menafkahkan hartanya di jalan Allah adalah serupa dengan sebutir benih yang menumbuhkan tujuh bulir, pada tiap-tiap bulir seratus biji. Allah 
melipat gandakan (ganjaran) bagi siapa yang Dia kehendaki. Dan Allah Maha Luas (karunia-Nya) lagi Maha Mengetahui." (QS. AlBaqarah: 261)

Sedangkan dalil dari Hadis adalah: "Apabila anak adam meninggal dunia, maka putuslah amalnya kecuali tiga perkara: sedekah jariyah, ilmu yang bermanfaat dan anak sholeh yang mendoakan orang tuanya." (HR. Ahmad).

Hadis lain adalah: "Diriwayatkan dari Ibnu Umar R.A bahwa Umar bin Khattab R.A memperoleh tanah ( kebun) di Khaibar, lalu ia dating kepada Nabi SAW untuk meminta petunjuk mengenai tanah itu, Ia berkata, «wahai Rasulullah SAW, saya memperoleh tanah di Khaibar yang belum pernah saya peroleh harta yang lebih baik bagiku melebihi tanah tersebut, apa perintah Engkau kepadaku mengenainya? Nabi SAW menjawab. «Jika kamu mau tahan pokoknya dan sedekahkan hasilnya." (HR. Bukhari).

Kedua hadis di atas merupakan dasar umum disyariatkannya wakaf dan juga dipakai oleh Majelis Ulama Indonesia (MUI) dalam fatwa kebolehan wakaf uang. Hadist pertama mendorong manusia untuk menyisihkan sebagian rezekinya sebagai tabungan akhirat dalam bentuk sedekah jariyah. Uang merupakan sarana yang paling mudah untuk disedekahkan. Pada hadist kedua, wakaf uang menjadikan hadist ini sebagai pijakan hukum karena menganggap bahwa wakaf uang memiliki hakekat yang sama dengan wakaf tanah, yakni harta pokoknya tetap dan hasilnya dapat dikeluarkan. Dengan mekanisme wakaf uang yang telah ditentukan, pokok harta akan dijamin kelestariannya dan hasil usaha atas penggunaan uang tersebut dapat dipakai untuk mendanai kepentingan umat.

Sedangkan dasar dalam Perundang-undangan di Indonesia adalah Undang-undang nomor 41 tahun 2004 tentang Wakaf yang telah di atur dalam Pasal 28 sampai Pasal 31, yakni: 
Pasal 28: Wakif dapat mewakafkan benda bergerak berupa uang melalui lembaga keuangan syariah yang ditunjuk oleh menteri

Pasal 29: 1) Wakaf benda bergerak berupa uang sebagaimana pasal 28 dilaksanakan oleh wakif dengan pernyataan kehendak Wakif dilakukan secara tertulis, 2) Wakaf benda bergerak berupa uang sebagaimana dimaksud dalam pasal 1 diterbitkan dalam bentuk sertifikat wakaf uang. 3) Sertifikat wakaf uang sebagaimana dimaksud dalam pada ayat 2 diterbitkan dan disampaikan oleh lembaga keuangan syariah kepada Wakif dan Nazhir sebagai bukti penyerahan harta benda wakaf.

Pasal 30: Lembaga keuangan Syariah atas nama nazhir mendaftarkan harta benda wakaf berupa uang kepada menteri selambatlambatnya 7 (tujuh) hari sejak diterbitkannya sertifikat wakaf uang.

Pasal 31: Ketentuan lebih lanjut mengenai wakaf benda bergerak berupa uang sebagaimana dimaksud pasal 28, 29, dan 30 diatur dalam peraturan pemerintah.

Mengenai Wakaf Tunai, Majelis Ulama Indonesia telah membolehkan Wakaf tunai, ini dibuktikan dengan adanya fatwa MUI Indonesia tanggal 11 Mei 2002 yang berbunyi:

1) Wakaf uang (cash wakaf/ waqfal-nuqud) adalah wakaf yang dilakukan seseorang, kelompok orang, lembaga atau badan hukum dalam bentuk uang tunai.

2) Termasuk ke dalam pengertian uang adalah surat-surat berharga.

3) Waqaf uang hukumnya jawaz (boleh).

4) Wakaf uang hanya boleh disalurkan dan digunakan untuk hal-hal yang dibolehkan secara syar'i. Nilai pokok wakaf uang harus dijamin kelestariannya, tidak boleh dijual, dihibahkan dan atau diwariskan.

Adapun yang menjadi pertimbangan MUI mengeluarkan fatwa tersebut diantaranya: 
1) Wakaf uang memiliki fleksibilitas (keluwesan) dan kemaslahatan besar yang tidak dimiliki oleh benda lain;

2) Pendapat Imam al-Zuhri (w. 124H.) bahwa mewakafkan dinar hukumnya boleh, dengan cara menjadikan dinar tersebut sebagai modal usaha kemudian keuntungannya disalurkan pada mauquf < alaih (Abu Su> ud Muhammad,: 20-21).

3) Mutaqaddimin dari ulama madzhab Hanafi (Wahbah alZuhaili, Damsyiq : Dar al-Fikr, 162) membolehkan wakaf uang dinar dan dirham sebagai pengecualian, atas dasar Istihsan bi al->Urfi, berdasarkan atsar Abdullah bin Mas>ud r.a: «Apa yang dipandang baik oleh kaum muslimin maka dalam pandangan Allah adalah baik, dan apa yang dipandang buruk oleh kaum muslimin maka dalam pandangan Allah pun buruk».

4) Pendapat sebagian ulama mazhab al-Syafi>i: «Abu Tsyar meriwayatkan dari Imam al-Syafi>i tentang kebolehan wakaf dinar dan dirham (uang)» (al-Mawardi, 379).

Wakaf uang yang dapat diwakafkan tersebut disyaratkan harus mata uang rupiah, namun bila masih dalam mata uang asing, maka dikonversi terlebih dahulu kedalam Rupiah. Dan minimal Rp. 1.000.000, serta 5 Lembaga Keuangan Syariah (LKS) Penerima Wakaf Uang (PWU) yakni; Bank Syariah Mandiri, BNI Syariah, Bank Muamalat, Bank DKI Syariah, Bank Mega Syariah Indonesia.

\section{Pemanfaatan Wakaf Uang untuk Infrastruktur}

Skema penyertaan modal swasta dalam pembangunan infrastruktur

Peran swasta dalam pembangunan infrastruktur sangat dibutuhkan sehingga pendanaan atau investasi untuk pembangunan infrastruktur dapat terpenuhi. Bentuk kerjasama ini biasa dikenal dengan istilah kerjasama pemerintah swasta atau konsesi. 
Berdasarkan model pengelolaan infrastruktur terdapat 4 (empat) model pengelolaan.

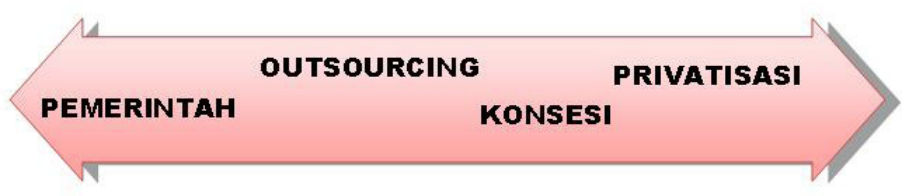

Di ujung sebelah kiri, pengelolaan sepenuhnya dikuasai dan dilaksanakan oleh pemerintah. Sementara di ujung sebelah kanan, pengelolaan sepenuhnya dikuasai dan dilaksanakan oleh pihak swasta. Pada model outsourcing, manajemen pengelolaan diambil dari pihak luar dimana pihak luar tersebut bisa berasal dari pihak swasta, sementara untuk konsesi pengelolaan diserahkan kepada swasta tetapi kepemilikan aset masih di tangan pemerintah dan pengelolaannya akan dikembalikan kepada pemerintah setelah seluruh jangka waktu yang diperjanjikan selesai (www.kppu.go.id).

Bentuk kerjasama konsesi dilakukan untuk sektor-sektor tertentu yang dengan alasan politik atau hukum dianggap tidak layak untuk dilakukan privatisasi. Konsesi dapat didefinisikan sebagai bentuk pemberian hak kepada pihak swasta untuk melakukan pembangunan atau pengelolaan pada sektor tertentu (biasanya di sektor infrastruktur), dimana pihak swasta menerima penghasilan dari hasil pengelolaan tersebut, namun hak milik dari lahan/tanah tersebut tetap di tangan pemerintah.

Bentuk konsesi bisanya muncul pada situasi dimana kompetisi dalam pasar tidak berkembang dengan baik, karena adanya monopoli alamiah atau kondisi struktur yang kurang mendukung. Dengan adanya konsesi diharapkan peluang terciptanya persaingan di pasar dapat terbuka sehingga memberikan keuntungan bagi konsumen. Dalam penyelenggaraan infrastruktur dengan menggunakan metode konsesi terdapat beberapa keuntungan yang dapat diperoleh, yaitu: 
1. Tercukupinya kebutuhan pendanaan yang berkelanjutan yang menjadi masalah utama pemerintah dalam membangun infrastruktur;

2. Meningkatkan kuantitas, kualitas, dan efisiensi pelayanan melalui persaingan yang sehat;

3. Meningkatkan kualitas pengelolaan dan pemeliharaan infrastruktur;

4. Mendorong prinsip "pakai-bayar", dan dalam hal tertentu dipertimbangkan kemampuan membayar dari si pemakai.

Dengan melihat keuntungan yang diperoleh tersebut, maka pemerintah perlu menciptakan kondisi yang kondusif bagi pihak swasta sebagai investor, agar mereka bersedia untuk bekerja sama dengan pemerintah dalam membangun infrastruktur. Langkah awal yang harus dilakukan dalam merancang konsesi adalah menentukan struktur, hak dan kewajiban para pihak. Satu hal yang cukup penting dalam proses ini adalah memastikan terdapat persaingan di dalamnya, artinya menciptakan struktur pasar yang berpihak pada persaingan.

Komponen lain dari perancangan adalah jangka waktu perjanjian konsesi. Terdapat beberapa konsekuensi dari penentuan jangka waktu perjanjian, perjanjian dengan jangka waktu yang lama akan menciptakan insentif yang layak bagi pihak swasta untuk melakukan investasi termasuk investasi dalam perawatan pada saat perjanjian konsesi tersebut berlangsung.

Sementara perjanjian dengan jangka waktu yang pendek akan semakin memperburuk masalah terkait dengan kurangnya insentif bagi pihak swasta untuk melakukan investasi saat kerjasama tersebut akan berakhir, itu sebabnya pihak swasta biasanya menaikkan biaya penawaran. Sisi positif dari kontrak jangka pendek pada KPS adalah dimungkinkannya tender yang kompetitif, namun konsesi jangka pendek dapat juga mengindikasikan bahwa terdapat ketidakpastian pada 
masa depan pasar. Proses pemilihan calon pemegang konsesi merupakan tahapan paling penting dimana dalam tahap inilah seharusnya persaingan itu terjadi. Proses lelang/tender merupakan cara paling efektif untuk menentukan pemegang konsesi, biasanya diawali dengan melakukan pengumuman yang tersebar luas ke seluruh kalangan atau melalui surat kabar nasional. Permasalahan yang sering muncul adalah ketika pihak incumbent memiliki keuntungan dengan akses informasi yang lebih banyak dibandingkan dengan mereka yang baru. Masalah ini dapat diatasi melalui panitia yang menyediakan informasi yang baik dan berimbang kepada seluruh penawar. Metode alternatif yang dapat digunakan selain menggunakan metode lelang adalah metode negosiasi dan beauty contests.

Selain itu, terdapat pula resiko praktek monopoli dari pemegang konsesi yang dapat dicegah dengan langkah-langkah sebagai berikut:

1. Struktur kontrak yang memungkinkan terciptanya persaingan dengan menyediakan banyak alternatif penyedia layanan/jasa sehingga dapat mengurangi posisi tawar dari pemegang konsesi;

2. Menghindari penggunaan kriteria tender yang dapat diubah, seperti penetapan tarif atau subjek yang dapat dimanipulasi seperti technical proposal;

3. Adanya performance bonds dalam kontrak sehingga pemegang konsesi yang gagal menjalankan kewajibannya akan memberikan ganti rugi;

4. Hak dari pemerintah sebagai pemberi konsesi untuk mengambil alih operasional dari pemegang konsesi apabila tidak dapat menjalankan pelayanannya sesuai dengan standar yang telah ditetapkan dalam kontrak; dan

5. Membebankan pada pemegang konsesi kewajiban untuk meneruskan menyediakan pelayanan sampai pemegang konsesi yang baru telah ditunjuk. 


\section{Pemanfaatan dana wakaf uang dalam pembiayaan pembangunan infrastruktur}

Wakaf tunai dapat digunakan sebagai solusi alternatif dalam pembiayaan infrastruktur di Indonesia. Dengan wakaf tunai, pembangunan infrastruktur tidak perlu memikirkan imbal hasil karena wakaf tunai bukan bersifat pinjaman. Dalam konsepnya, wakaf dianggap sebagai sumber aset yang memberi pemanfaatan sepanjang masa. Namun permasalahan yang berkembang kemudian adalah persoalan pengumpulan, pengelolaan, dan penyaluran dana wakaf tunai yang membutuhkan penanganan serius. Di Indonesia studi perwakafan masih sering berkutat pada segi hukum fikih (mu'amalah) yang jarang menyentuh pada manajemen perwakafan. Padahal, seharusnya wakaf bisa dijadikan sebagai sumber dana dan aset ekonomi yang senantiasa dapat dikelola secara produktif dan memberi hasil kepada masyarakat (Tim Direktorat Pemberdayaan Wakaf Kemenag RI, 2007: 94).

Dalam sisi pengumpulannya, wakaf masyarakat dapat disetorkan melalui Badan Wakaf Indonesia yang berperan sebagai lembaga independen untuk mengembangkan perwakafan di Indonesia, atau melalui lembaga keuangan syariah penerima wakaf uang yang sudah mendapatkan ijin dari pemerintah. Dalam pelaksanaannya, Badan Wakaf Indonesia dapat dibantu oleh Kementerian Agama untuk menghimpun wakaf. Kemudian dana terhimpun dalam satu periode tertentu (satu tahun, enam bulan atau tiga bulan). Dana wakaf tersebut dapat disetorkan kepada Kementerian Keuangan guna dimasukkan kepada kas negara. Dalam perannya, Kementerian Keuangan menganggarkan dana wakaf tersebut untuk pembangunan infrastruktur. Berbeda dengan utang, dana wakaf merupakan dana murah sehingga tidak harus menawarkan imbal hasil yang menarik untuk mendapatkannya, namun demikian, tetap perlu diperhatikan tentang kelangsungan dari dana wakaf tersebut, karena pada prinsipnya pengelolaan dana wakaf haruslah dapat memberikan manfaat secara terus 
menerus (sustainable benefit) bagi kemaslahatan umat, sehingga pada saat proyek infrastruktur tersebut telah dapat beroperasi dan mampu menghasilkan keuntungan secara ekonomi, maka dana wakaf dapat dikembalikan lagi ke Badan Wakaf Indonesia untuk nantinya dapat dimanfaatkan untuk pengembangan ekonomi atau kemanfataan dan kemaslahatan bagi umat, dengan ditambah bagi hasil dari pengelolaan hasil infrastruktur.

Dan oleh karena dana wakaf adalah milik masyarakat muslim, yang diperuntukkan untuk memberikan manfaat secara terus menerus bagi kemaslahatan umat. Maka dalam penyertaan dana wakaf dalam pembangunan infrastruktur haruslah menempatkan asas kehati-hatian pada aspek yang utama. Perlu ada penelitian dan kajian atas nilai infrastruktur dari sisi kemanfataannya bagi kemaslahatan umat dan peningkatan ekonomi umat, dan sisi resiko penyertaan dana wakaf dalam proyek infrastruktur. Hal ini dimaksudkan agar nantinya tidak ada kesalahan yang kemudian menyebabkan resiko hilangnya dana wakaf, karena proyek infrastruktur yang dibiayai oleh dana wakaf ternyata tidak atau kurang memberikan manfaat bagi kemaslahatan dan peningkatan ekonomi umat, atau bahkan justru merugi dan pada akhirnya menyebabkan hilangnya dana wakaf.

\section{Simpulan}

Berdasarkan uraian diatas, maka Penulis dapat menyimpulkan bahwa dana wakaf tunai dapat digunakan untuk melakukan pembiayaan pembangunan infrastruktur, karena pada dasarnya tujuan antara pembangunan infrastruktur dan wakaf adalah sama yaitu untuk meingkatkan kesejahteraan sosial masyarakat (umat). Dengan adanya infrastruktur yang baik, maka akan meningkatkan produktifitas dan peningkatan ekonomi, sehingga dapat meningkatkan kesejahteraan masyarakat. Demikian pula dengan wakaf, dimaksudkan untuk memberikan kesejahteraan bagi masyarakat. Namun oleh karena dana wakaf adalah milik masyarakat umum yang diserahterimakan kepada 


\begin{abstract}
Ahmad Syafiq
Badan Wakaf untuk dikelola, maka dalam penyertaan dana wakaf sebagai salajh satu sumber dana untuk pembangunan proyek infrastruktur, maka perlu dikedepankan aspek kehatihatian. Aspek kehati-hatian ini dapat dilakukan dengan melakukan kajian-kajian secara mendalam dengan melibatkan pakar dari berbagai bidang keilmuan tentang prospek dari proyek infrastruktur tersebut bagi peningkatan kesejahteraan umat, sehingga nantinya dana wakaf dapat kembali memberikan keuntungan yang berkelanjutan (sustainable benefit) dan dapat dimanfaatkan lagi untuk pemberdayaan umat yang lain.
\end{abstract}

\title{
Daftar Pustaka
}

Abu Zahrah, Muhadharat fi al-Waqf, Dar al-Fikr al-'Arabi, Beirut, 1971.

Ahmad Djunaedi dan Thobieb Al-Asyar, Menuju Era Wakaf Produktif: Sebuah Upaya Progrsif Untuk Pemberdayaan Ummat Mitra Abadi Press, Jakarta, 2006.

http:/ / pusat.baznas.go.id/posko-aceh/dari-konferensi-islamdan-peradaban-ke-konsep-bank-wakaf/).

http:/ / www.dakwatuna.com/2016/03/05/79433/optimalisasipotensi-wakaf-uang-pembangunan-sumber-daya-dankesejahteraan-rakyat-kecil/\#ixzz4XVYRc1gh ).

http:/ / www.icmi.or.id/blog/2015/04/zainulbahar-noor-pendirian-bank-wakaf-sangat-perlu);

Ibnu Abidin, Rad al-Mukhtar 'ala Dar al Mukhtar, Juz II, al Munirah, Mesir, tt.

Majalah Tempo, Edisi Oktober 2017.

Muhammad Abid Abdullah Al-Kabisi, Hukum Wakaf: Kajian Kontemporer Pertama Dan Terlengkap Tentang Fungsi Dan 
Pengelolaan Wakaf Serta Penyelesain Sengketa Wakaf, DDR dan IIMan, Jakarta, tt.

Muhammad Ibn Bakar Ibn Mandzur, Lisan al-'Arab, Jilid 11, AlMishriyah, Bulaq, $1301 \mathrm{H}$.

Prihatini, F. et. al. Hukum Islam Zakat dan Wakaf, Kerjasama Penerbit Papas Sinar Mentari dengan Badan Penerbit Fakultas Hukum Universitas Indonesia, Jakarta, 2005.

Sudirman Hasan, Wakaf Uang Tunai: Perspektif fiqih, Hukum Positif dan Manajemen. UIN Maliki Press, Malang, 2011.

Tim Penyusun, Fiqih Waqaf, Direktorat Pemberdayaan Wakaf Dirjen Bimbingan Masyarakat Islam Departemen Agama RI, Jakarta, 2006.

Tim Penyusun, Perkembangan Pengelolaan Wakaf di Indonesia, Direktorat Pemberdayaan Wakaf Dirjen Bimbingan Masyarakat Islam Departemen Agama RI, Jakarta, 2006.

UU No. 41 Tahun 2004 tentang Wakaf. 
Ahmad Syafiq

Halaman ini bukan sengaja untuk di kosongkan 